Esta publicación cientifica en formato digital es continuidad de la revista impresa ISSN-Versión Impresa 0798-1406 / ISSN-Versión on line 2542-3185Depósito legal pp
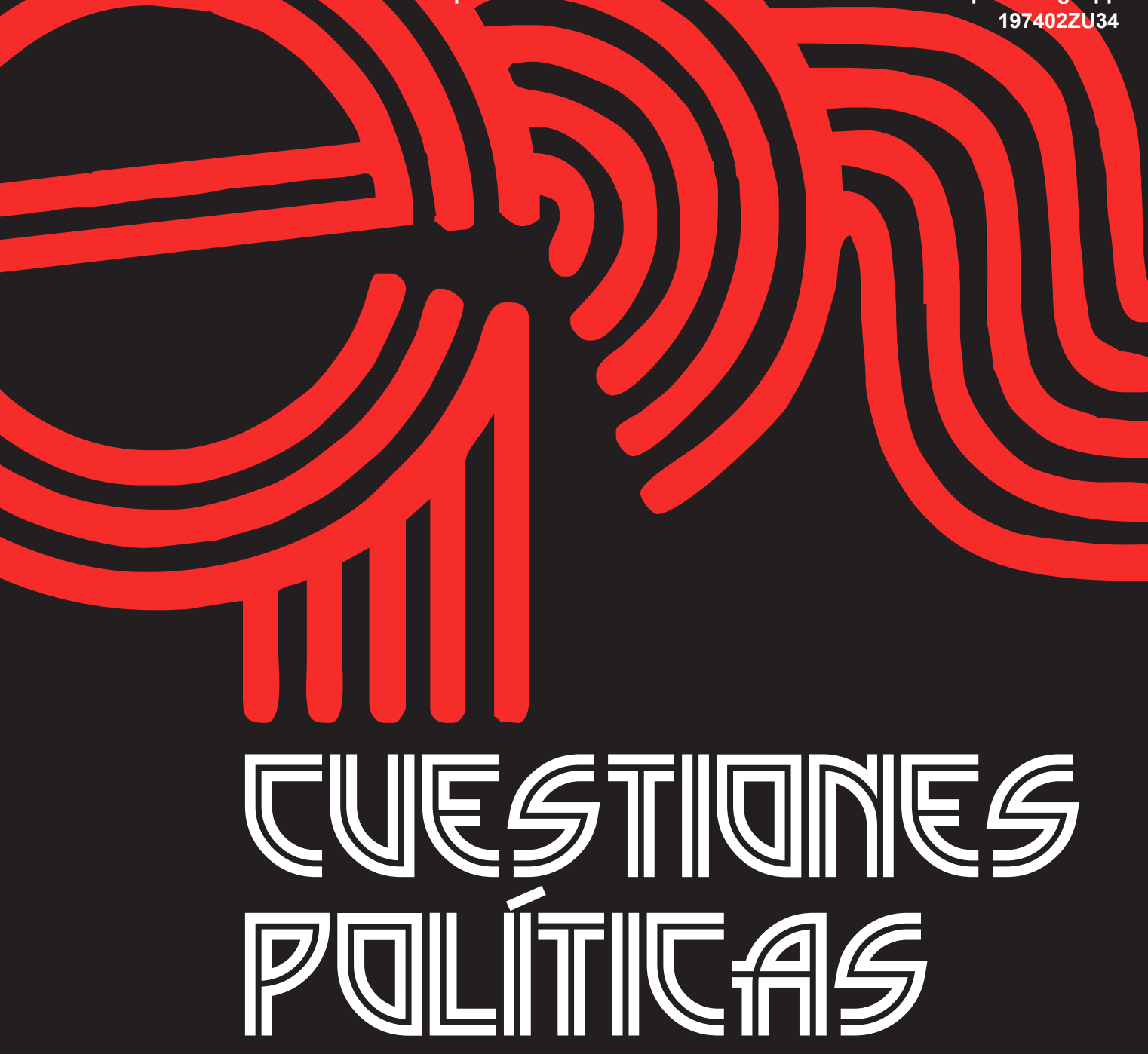

Instituto de Estudios Políticos y Derecho Público "Dr. Humberto J. La Roche" de la Facultad de Ciencias Jurídicas y Políticas de la Universidad del Zulia Maracaibo, Venezuela
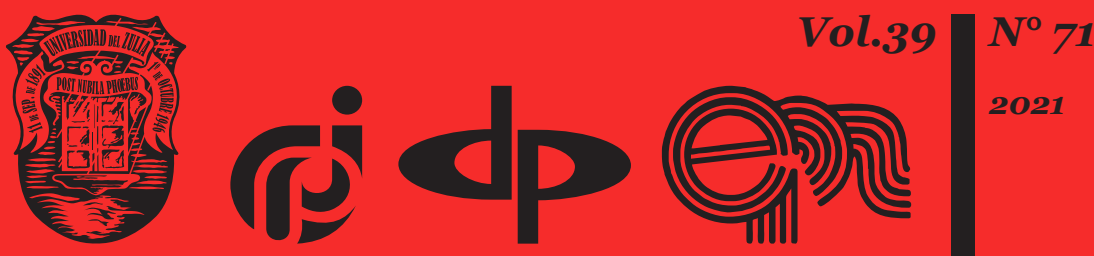


\title{
The effect of individual differences on the cognitive processes of a witness during interrogation
}

\author{
DOI: https://doi.org/10.46398/cuestpol.3971.39
}

\author{
Marina Anatoleyvna Kaluzhina * \\ Vadim Victorovich Verstov ** \\ Yuri Alekseevich Bondarenko *** \\ Tatiana Sergeevna Balugina **** \\ Alexander Ivanovich Natura*****
}

\begin{abstract}
The article presents an analysis of the different existing conceptions of interrogation and, at the same time, indicates the ambiguity of approaches to the examination of witnesses according to the type of crime, the body conducting the investigation and the tactics used. The study explores the effect of individual differences on the cognitive processes of witnesses in a simulated interrogation. The authors conducted a survey using the Eysenck Personality Inventory (EPI) method. The groups of witnesses are divided not by the types of temperament per se but according to the set of temperamental characteristics (introversion and extraversion; neuroticism) and controlling the sincerity of the interviewees during the test, which significantly improves the reliability of the conclusions (Eysenck Personality Inventory). Finally, the study experimentally demonstrates that the speed of the mental reactions of the witnesses is not uniform and varies according to their temperamental characteristics. This gives reason to affirm the need to adapt to different groups of witnesses before and during their interrogation, giving an account of the peculiarities of their perception
\end{abstract} and processing of information.

Keywords: interrogation; witness; personality; individuality; temperament.

Kuban State University, Krasnodar, Russia; Research Institute of the Federal Penitentiary Service of Russia, Moscow, Russia. ORCID ID: https://orcid.org/oooo-0003-4603-4129

** Kuban State University, Krasnodar, Russia. ORCID ID: https://orcid.org/oooo-0oo2-8051-8840

*** Kuban State University, Krasnodar, Russia. ORCID ID: https://orcid.org/oooo-0002-5750-685X

**** Kuban State University, Krasnodar, Russia. ORCID ID: https://orcid.org/oooo-00o3-4465-1668

***** Kuban State University, Krasnodar, Russia. ORCID ID: https://orcid.org/oooo-0002-9567-7705 
Marina Anatoleyvna Kaluzhina, Vadim Victorovich Verstov, Yuri Alekseevich Bondarenko, Tatiana Sergeevna Balugina y Alexander Ivanovich Natura

644 The effect of individual differences on the cognitive processes of a witness during interrogation

\section{El efecto de las diferencias individuales en los procesos cognitivos de un testigo durante el interrogatorio}

\section{Resumen}

El artículo presenta un análisis de las diferentes concepciones existentes del interrogatorio y, al mismo tiempo, indica la ambigüedad de los enfoques del interrogatorio de testigos según el tipo de delito, el organismo que realiza la investigación y las tácticas utilizadas. El estudio explora el efecto de las diferencias individuales en los procesos cognitivos de los testigos en un interrogatorio simulado. Los autores realizaron una encuesta utilizando el método Eysenck Personality Inventory (EPI). Los grupos de testigos se dividen no por los tipos de temperamento per se sino en función del conjunto de características temperamentales (introversión y extraversión; neuroticismo) y controlando la sinceridad de los entrevistados durante la prueba, lo que mejora significativamente la fiabilidad de las conclusiones (Inventario de Personalidad de Eysenck). Finalmente, el estudio demuestra experimentalmente que la velocidad de las reacciones mentales de los testigos no es uniforme y varía según sus características temperamentales. Esto da razón para afirmar la necesidad de adaptarse a diferentes grupos de testigos antes y durante su interrogatorio, dando cuenta de las peculiaridades de su percepción y procesamiento de la información.

Palabras clave: interrogatorio; testigo; personalidad; individualidad; temperamento.

\section{Introduction}

The existing and applied systems of methods for crime witness interrogation show insufficient effectiveness in exposing lies and preventing self-incrimination and perjury. This situation is due to the widespread dissemination of information about the means and methods of police work and the wide spread of practical psychological techniques that allow adjusting one's mental profile before and after committing a crime. In this situation, the arsenal of police interrogation tools needs to be strengthened by new techniques not directly associated with an open confrontation with a witness or a suspect (Horák et al., 2021; Soldz et al., 2017).

An increased interest in the psychological foundations of interrogation is observed in recent years. Ultimately, this interest is manifested in the concept of mediated interrogation that does not directly address the core issues for which it is conducted. An essential aspect of this process is the cognitive abilities and emotional state of the interrogated person. All of the above has a significant impact on the interrogation program, which leads to 
its practical individualization (Morgan et al., 2020; Sambrano et al., 2021; Vrij et al., 2019).

The inclusivity of interrogation methods also manifests in choosing the interrogation setting designed to obtain a confession or to exclude selfincrimination. These methods are quite diverse, but the practice has revealed their usefulness in creating a comfortable psychological environment and establishing and maintaining psychological contact with the witness, as well as ample opportunities to apply the emotional components of the interrogation and the generally lower number of false testimonies given (Swanner et al., 2016).

It can be stated that the conducted research on the course of mental processes in the minds of the interrogated primarily focuses on assessing their emotional state. On this basis, criteria for the evaluation of the mental state of the interrogated, their prevailing psychological characteristics, fears, and directions for establishing cooperation are identified.

Analysis of literature on the studied problem points to efficient research on the feelings of interrogated persons as a basis for the construction of methods for examining their mental processes. The "feeling-as-information" theory introduced into the scientific arsenal explores changes in a person's perception of information depending on their current emotional state (anger, sadness, happiness) and the resulting erroneous data, false confessions of guilt, and other untruthful information. It is found that different emotional states can produce similar emotions and accounting for this pattern allows supplementing the interrogation program for further precise correction and adjustment to the witness (Sambrano et al., 2021).

The situation of interrogation implies the objective of obtaining credible testimony from a witness to provide the court with a basis for the allegations of the prosecution or defense (Rudenko and Senchikova, 2021).

Our study reflects the individual characteristics of witnesses as mass participants in investigations. We chose to differentiate witnesses by their temperament since it is a fundamental characteristic of any personality. Knowledge of the patterns of emotional and cognitive processes serves as a prerequisite for forensic and psychological analysis of a witness' personality and has an impact on the processes of testimony formation and the identification of deliberately false testimony.

The goals of the study lie in the identification and analysis of individual differences in witnesses' cognitive processes in the situation of a simulated interrogation. Determining such individual differences is required for more rational planning of witness interrogation.

The methods used in the study include the analysis and synthesis of scientific information, summarization and classification of factual data, 
Marina Anatoleyvna Kaluzhina, Vadim Victorovich Verstov, Yuri Alekseevich Bondarenko, Tatiana Sergeevna Balugina y Alexander Ivanovich Natura

situation modeling, comparison method, and testing (Eysenck Personality Inventory determining the types of temperament; Schulte tables studying the characteristics of attention).

The obtained data are processed using the methods of primary and secondary mathematical statistics, as well as the mathematical method of data interpretation. The psychological foundations of investigative tactics are considered as their starting points serving as a means of determining the tactical techniques. Works on general and legal psychology are analyzed (Antonian et al., 1996; Enikeev, 1996; Granovskaia, 1997; Ratinov, 1967; Vedernikov, 1968).

Interrogation requires the investigator to have a set of qualities such as professional culture and ethics, knowledge and understanding of human psychology, and skilled psychological influence, as well as the mastery of tactical and criminalistic techniques. An interrogation involves obtaining information regarding the factual background of the event under investigation from a witness. The purpose of an interrogation is to obtain a testimony that is the most complete and objectively reflects reality.

Essentially, interrogation is the most "psychologized investigative action" (Antonian et al., 1996) associated with the personal characteristics of the investigator and the witness, as well as the individual psychological characteristics of their interaction. Each person has a unique reaction to different arguments, their own pace and rhythm of conversation, and without accounting for the individual characteristics of a person, it will be difficult for an investigator to establish contact with a stranger. This obliges an investigator to have mastery of the means of interaction relying on the knowledge of the mental processes of an individual.

Thorough preparation for an interrogation implies gathering information on the personality of a witness to determine the model of their actions and behavior during interrogation. Thus, from the very beginning of studying the personality of the interrogated, an investigator must focus their professional attention on the typology of their personality, as well as on the individual properties of the psyche that determine the dynamics of a person's mental activity (Kashapov and Serafimovich, 2020). Here, emphasis is put on the behavioral stereotypes manifesting in the speed of reaction to stimuli and the subsequent correction of behavior prior to a new reaction to a stimulus.

The commonly used psycho-typological methods are based on the classic psychological division of people into extroverts and introverts. The criminalistic study of personality began with typological studies and several authors argue that it is rational to study the temperament of a person who committed a crime (Krivoshein, 2001). 
Considering the typology of temperament, temperament meaningfully incorporates not only personal and behavioral aspects, but also the cognitive processes of an individual that help to work with them. The content side of this work is designing a plan of conversation with a witness accounting for the risks that arise for each type of temperament.

It should be noted that the dynamic side of interrogation is essentially associated with temperament, as well as with the cognitive processes of the person being interrogated (e.g., attention and memory). If an investigator wants to achieve success, they must plan the pace, rhythm, duration, and level of intensity of the interrogation considering the individual mental characteristics of the interrogated.

The study and identification of the types of the temperament of the interrogated allow determining the specifics of their cognitive sphere and emotional behavior during interrogation (Vilenskaya, 2020) which, in turn, allows individualizing the interrogation tactic. An investigator's use of psychological knowledge on the individual mental processes and specific characteristics of a person makes it possible to determine the set of tactical techniques to be used during interrogation in advance.

Physician Claudius Galen proposed the first typology of temperament more than two thousand years ago. The four types identified by him are currently considered as the main ones - sanguine, choleric, phlegmatic, and melancholic. While Galen associated temperament with the patterns of metabolism in the body, I.P. Pavlov indicated the contingency of temperament on the type of nervous system.

The scientist revealed the patterns of higher nervous activity and found them to be the basis of temperament along with individual characteristics of conditioned reflex activity. Pavlov believed that the characteristics of nervous processes determine the type of nervous activity, which, in turn, is closely associated with the type of temperament (strength, weakness, equilibrium, and mobility of the nervous system) (Averin, 1999). Experiments in practical psychology have supported the legitimacy of Pavlov's approach and led to it becoming a basis for further detalization.

The additional properties of the nervous system (dynamism and lability) were also substantiated which provided for the integration of temperament into the structure of personality. Temperament shapes the formal and dynamic, process aspect of the human psyche and answers the "how" question. Temperament manifests in all spheres of human mental activity: the emotional, cognitive, and volitional. Thus, temperament is a biological foundation for personality based on the characteristics of the nervous system and associated with the structure of a person's body (constitution) and metabolism (Balin and Il'ina, 2020). 
Marina Anatoleyvna Kaluzhina, Vadim Victorovich Verstov, Yuri Alekseevich Bondarenko, Tatiana Sergeevna Balugina y Alexander Ivanovich Natura

648 The effect of individual differences on the cognitive processes of a witness during interrogation

Although research utilizes different criteria for distinguishing between the types of temperament, the typology retains its four-member structure.

A sanguine person (strong, balanced, agile) is emotionally quick, easily adapts to the changing life conditions, their main desire is a thirst for pleasure. In a complex unexpected situation, they hold themselves together without losing emotional tonus. This type has a high resistance to the difficulties of life, they are sociable and mobile, easily converge with new people, and are not characterized by consistency in interaction. They can quickly lose interest in an activity if it ceases to be entertaining.

This type of witness has a strong balanced nervous system, does not react to weak influences, is not vulnerable, and has balanced volitional and communicative qualities. They are active in their activity when interested and become bored when uninterested.

A choleric person (strong, unbalanced) is hardworking and ready to react quickly, but it is difficult for them to "get along" with themselves. The choleric nervous system is characterized by a predominance of excitation over inhibition. Such a person has a lot of vitality but not enough selfcontrol, they can be fiery and intemperate. When they proceed with a new activity, they devote themselves to it passionately and with full power, but the strength and energy last for a short time, power comes to an end, and they end up in a decadent mood.

The nervous system of such witnesses is unbalanced, and cyclical moods dominate. In their interactions with people, such a person is impatient, shouty, aggressive, and short-tempered, which makes testimonies excessively emotional.

A phlegmatic person (strong, balanced, inert) is calm, balanced, has an increased capacity for work, "internally" leveled, but is "stick-in-themud", it is very difficult for them to abandon the established attitudes and stereotypes, enter a new job, get out of the usual pace.

Such a witness firmly remembers everything they perceive but has difficulties if it is necessary to change the daily routine, work, and friends, it is very hard for them to adapt to new conditions of life. They can resist prolonged stimulation for a long time.

A melancholic person (weak) resists the influence of strong stimuli poorly, therefore, can often be passive and inhibited. Strong stressors and stimuli can lead to disrupted behavior.

This type of witness is fearful, restless in behavioral acts, anxious, their stamina is weak. A minor occasion can bring them to tears, they are insecure, timid, lack energy, and have little social interaction. 
Aside from the characteristics of temperament, important aspects of personality are cognitive processes and emotional qualities that affect the activity and behavior of individuals in social and legal situations, especially in situations of interrogation.

In an interrogation, a witness is the bearer of evidentiary information. Obtaining this information is, however, complicated by the psychological characteristics of a witness. Only the knowledge of these specifics can ensure the effectiveness of investigative action by obtaining complete and objectively new data.

During witness interrogation, it is necessary to pay attention to the factors that affect the formation of personal information (e.g., attention span, concentration, stability of attention). This work is often overlooked by young investigators, but it contributes to the fastest diagnosis of the individual characteristics of a witness and allows for the adjustment of the issues under discussion.

Attention is often defined as the focus and concentration of a person's consciousness on a particular object. The object of attention can be anything: the questions asked by the investigator, actions, thoughts, feelings, and even the inner world of the witness.

Attention is also understood as the identification or selection of relevant and personally significant signals, orientation, and concentration of consciousness on certain objects of activity with distraction from the rest. Just as memory, attention belongs to "cross-cutting" mental processes as it is present at all levels of the mental organization (Enikeev, 1996).

At the same time, attention is a cognitive process that ensures the organization of the incoming information based on the priority of objectives faced by the subject.

Some researchers tend to equate attention with the orienting activity (Gippenreiter, 2001; Granovskaia, 1997). Others (Enikeev, 1996; Leonov, 2018; Prohorov, 2020) consider attention to be an independent form of mental activity, specifically a psychological form of control.

An objectively immeasurable quantitative category is the concentration of attention, that is, the degree of its focus. Concentrated attention is directed to one object (type of activity) and does not extend to others. Witnesses with a high degree of concentration are the most preferable since focusing on a single object for a long period of time contributes to remembering the details of an event or phenomenon.

It is worth noting that the concentration (focus) of attention on a certain object entails distraction from everything beside it, as concentration is a prerequisite for comprehending and capturing the information coming into the brain making the reflection clear and distinct. 
Marina Anatoleyvna Kaluzhina, Vadim Victorovich Verstov, Yuri Alekseevich Bondarenko, Tatiana Sergeevna Balugina y Alexander Ivanovich Natura

Focused attention is characterized by high intensity, which is necessary to perform important activities. Among witnesses, good characteristics of concentration are demonstrated by the phlegmatic and sanguine types.

Although attention presents a cognitive process providing the systematization of the incoming information depending on the priority of the objectives faced by a person, it is not an independent mental function. It cannot be identified in a witness as it presents a special form of human mental activity incorporated in all types of mental processes (memory, imagination, representation). At the same time, attention is a vital condition for high-quality and long-term activity, such as an interrogation.

The supports the need to have knowledge of and focus one's professional attention on the cognitive process of attention, especially regarding the effect of temperament on a person's attention in the course of witness interrogation.

For example, when interrogating a melancholic, it is necessary to account for the individual properties of their nervous system. They may be frightened by new surroundings and easily fatigued, they have little capacity for work, due to which their attention concentration decreases. Here, concentration becomes one of the basic properties of attention and determines the level of performance, which is especially important in an interrogation due to the established time limit.

To achieve the goal of the study, psychological testing of the group of subjects was conducted before and after the simulated interrogation situation. The sample of the study comprises 30 male and female subjects at the average age of 21.6 years old and ranging from 20 to 45 years old.

Situational modeling allowed assessing the subjects' attention span before the simulated "witness interrogation situation" and after it. In turn, this approach provided the opportunity to compare and contrast the characteristics of the subjects' cognitive processes with their temperamental characteristics.

The simulated interrogation situation lasted no longer than three hours for each study participant.

\section{Methods}

The psychodiagnostic assessment of the subjects using the Eysenck Personality Inventory (EPI) provides data on the degree of manifestation of temperamental characteristics (extraversion and neuroticism) and sincerity (the lie scale) in them, as well as their overall type of temperament. These results are presented in Table 1 (Mironova, 2005). 
Table 1. Results of Eysenck Personality Inventory*

\begin{tabular}{|l|c|c|c|c|c|c|c|c|}
\hline & \multicolumn{7}{|l|}{ Type of temperament } \\
\hline \multirow{2}{*}{ Scale } & \multicolumn{2}{|c|}{ melancholic } & \multicolumn{2}{c|}{ choleric } & \multicolumn{2}{c|}{ phlegmatic } & \multicolumn{2}{c|}{ sanguine } \\
\cline { 2 - 9 } & Mean & SD & Mean & SD & Mean & SD & Mean & SD \\
\hline $\begin{array}{l}\text { Extraversion/ } \\
\text { introversion }\end{array}$ & 10.5 & 0.57 & 16.4 & 2.5 & 10.6 & 1.5 & 15 & 2 \\
\hline Neuroticism & 17 & 1.7 & 17.4 & 2.7 & 10 & 1 & 8.8 & 2.1 \\
\hline Sincerity & 3.5 & 0.5 & 4 & 1.4 & 3.3 & 0.5 & 4.4 & 1.2 \\
\hline
\end{tabular}

The data in Table 1 show that the "melancholic" and "phlegmatic" subjects were sincere when tested, while the "choleric" and "sanguine" groups show an excess on the sincerity scale, that is, the subjects could be orientated toward social approval and social desirability when answering the test questions (Figure 2).

After that, the subjects were divided into groups according to the type of temperament using Eysenk's “circle”.

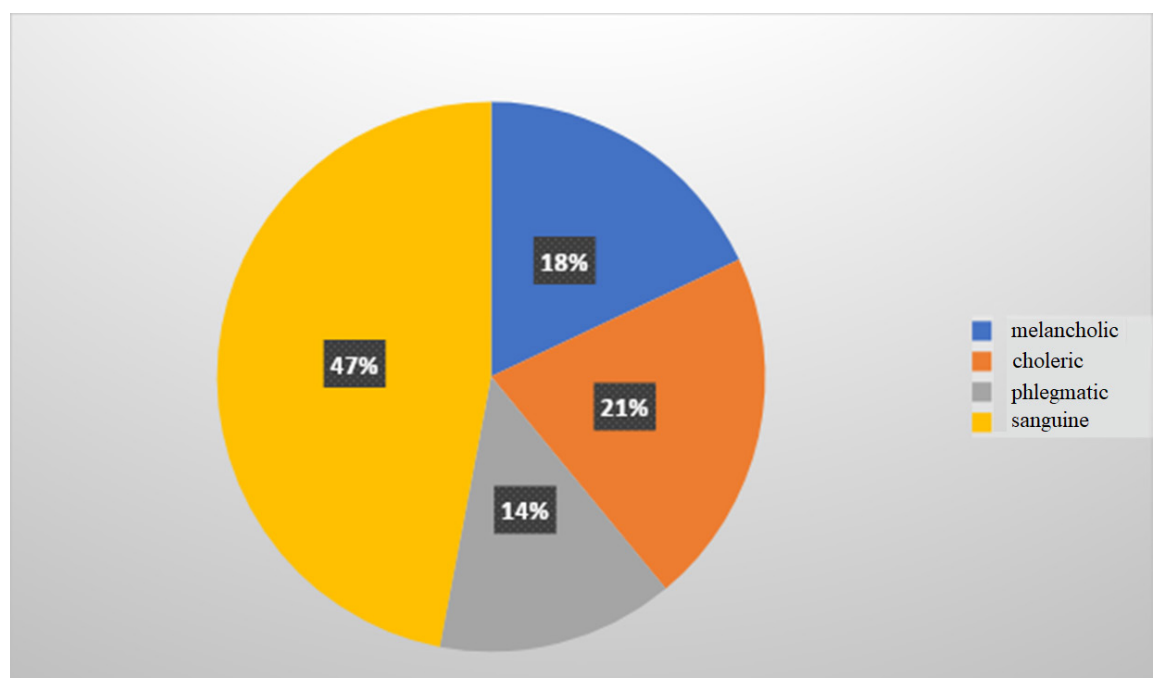

Figure 1. Distribution of the types of temperament (in \%)*

${ }^{*}$ Compiled by the authors 
Marina Anatoleyvna Kaluzhina, Vadim Victorovich Verstov, Yuri Alekseevich Bondarenko, Tatiana Sergeevna Balugina y Alexander Ivanovich Natura

652 The effect of individual differences on the cognitive processes of a witness during interrogation

Figure 1 demonstrates that the distribution of the sample by the types of temperament is uneven: choleric people make up $21 \%$ of the sample (high extraversion and neuroticism), the largest group is the sanguine, $47 \%$ of the sample (high extroversion and low neuroticism), 15\% of subjects are phlegmatic (high introversion and low neuroticism), and $18 \%$ are melancholic (high introversion and high neuroticism) (Figure 2).

Here we have to note that this distribution by the types of temperament cannot be considered precise as the distinction between the low and high scores does not take average scores into account. Thus, the difference in just one point can lead to assignment to different types of temperament. In this regard, we can once again note that it is more accurate to consider the expression of temperamental characteristics as a characteristic of temperament and not the type of temperament per se.

In addition, people with a strongly pronounced type of temperament are rarely found, most personalities are characterized by an intricate intertwining of temperament types. In unusual situations, such as an interrogation, the characteristic traits of one type of temperament manifest fully and vividly, for example, the choleric tendency to violent and affective response to a stressful situation.

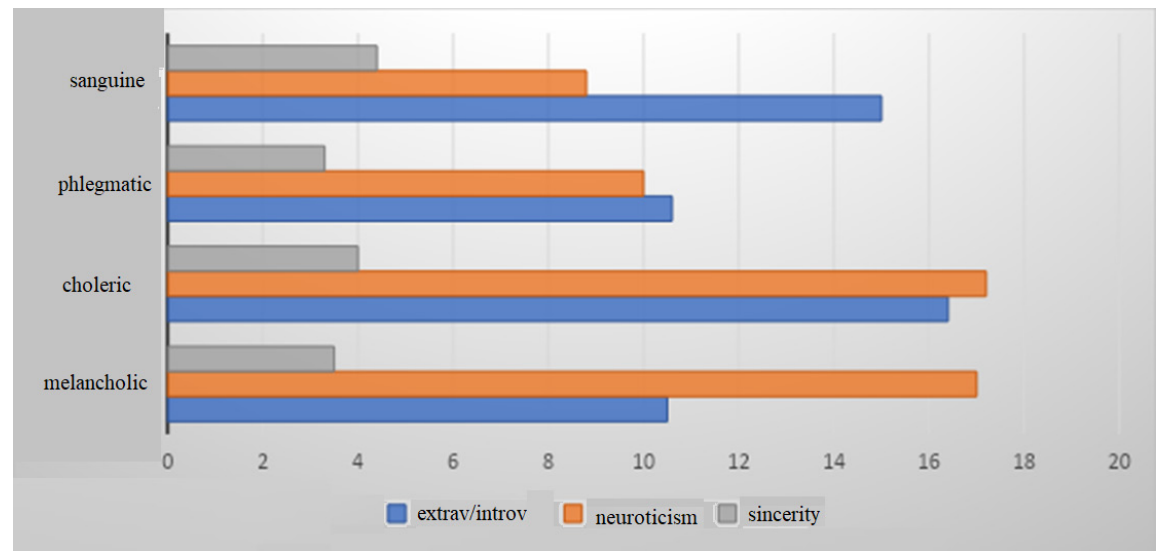

Figure 2. Distribution of the types of temperament (scales)*

* Compiled by the authors

Further on, we deployed Schulte tables to assess the witnesses' focus of attention. The tables are used to test people of various age groups to determine the subjects' information perception rate depending on the type 
of their temperament before and after the interrogation situation. Schulte tables are square tables of 5 columns and 5 rows filled with numbers from 1 to 25 placed in a random order, the study participants were presented with five Schulte tables in two sessions (before and after the interrogation).

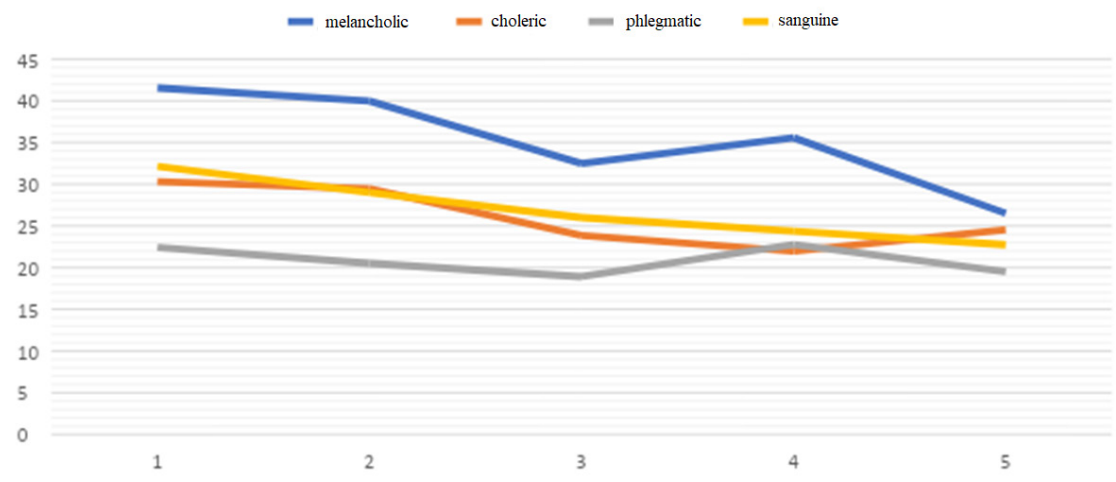

Figure 3. Distribution based on the Schulte Table results (pre-interrogation)*

* Compiled by the authors

The results of the study (see Figures 3 and 4) show that the group of melancholics is more prone to lower attention focus, poor ability to switch attention, and low stability of attention (before and after the situation of interrogation). Naturally, this will make it significantly more difficult to establish contact and dialogue in an interrogation situation with a witness of a melancholic temperament type (Vedernikov, 1968).

Table 2. Schulte Table results (pre-interrogation)*

\begin{tabular}{|l|l|l|l|l|l|}
\hline & \multicolumn{5}{|l|}{ Schulte Table (pre-interrogation), in seconds } \\
\hline & 1 & 2 & 3 & 4 & 5 \\
\hline melancholic & 41.54 & 39.99 & 32.47 & 35.58 & 26.5 \\
\hline choleric & 30.318 & 29.44 & 23.854 & 21.964 & 24.52 \\
\hline phlegmatic & 22.416 & 20.51 & 18.916 & 22.76 & 19.53 \\
\hline sanguine & 32.140 & 29.005 & 25.99 & 24.345 & 22.74 \\
\hline
\end{tabular}


Marina Anatoleyvna Kaluzhina, Vadim Victorovich Verstov, Yuri Alekseevich Bondarenko, Tatiana Sergeevna Balugina y Alexander Ivanovich Natura

654 The effect of individual differences on the cognitive processes of a witness during interrogation

The phlegmatic group demonstrates stable results both pre- and postinterrogation: the distribution and switchability of attention is less mobile, even though this type is "stick-in-the-mud" and needs a longer adaptation to the situation of interrogation due to the long period of time required for involvement in the dialogue.

In the most populous group of the sample, the sanguine and choleric subjects, the distribution, switchability, and attention and mobile. When interrogating choleric and sanguine witnesses, an investigator can proceed from knowing that the pace, rhythm, and intensity of the interrogation may be high, but not so long with a choleric, the introductory stage of the interrogation and the long establishment of contact may be reduced to a minimum, and the transition from one topic to another may be performed without lengthy preliminary preparation.

Table 3. Schulte Table results (post-interrogation)*

\begin{tabular}{|l|l|l|l|l|l|}
\hline & \multicolumn{5}{|l|}{ Schulte Table (post-interrogation), in seconds } \\
\hline & 1 & 2 & 3 & 4 & 5 \\
\hline melancholic & 26.38 & 27.375 & 24.8575 & 28.105 & 28.97 \\
\hline choleric & 22.806 & 22.414 & 21.146 & 23.458 & 21.42 \\
\hline phlegmatic & 18.06 & 18.457 & 17.73 & 20.47 & 19.83 \\
\hline sanguine & 22.897 & 21.942 & 22.074 & 22.25 & 21.56 \\
\hline
\end{tabular}

* compiled by the authors

Thus, determining the temperament of the person under interrogation is important when considering how the investigator needs to structure their interrogation tactics. Determining the temperament and attention concentration via observation, conversation, and familiarization with the open profile in social media allows obtaining necessary and valuable information on the psychological state of the person involved in a criminal situation, as well as their individual characteristics now. This constitutes the psychological essence of witness interrogation (Ratinov, 1967). 


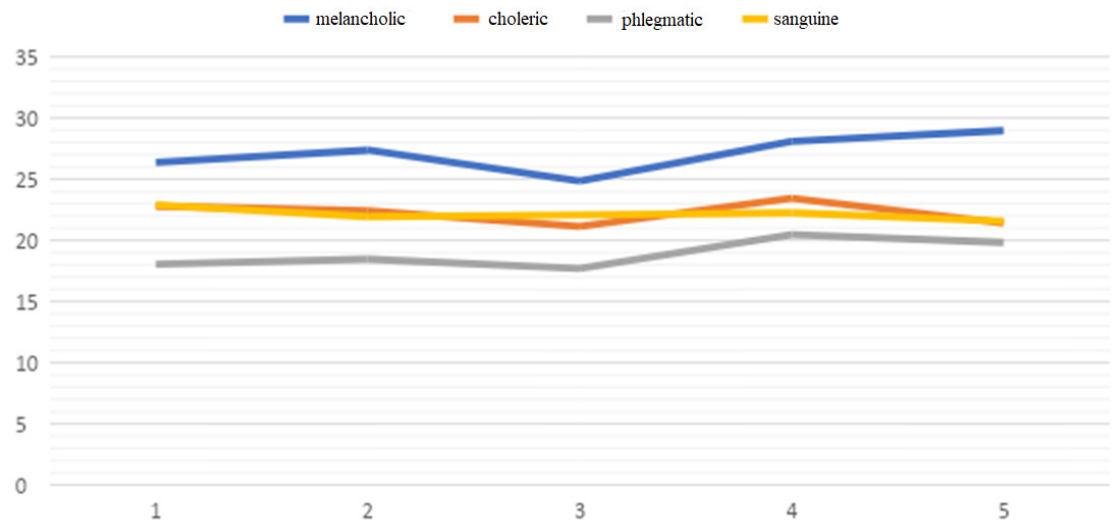

Figure 4. Distribution based on the Schulte Table results (post-interrogation)*

* Compiled by the authors

\section{Results}

Thus, when questioning choleric and sanguine people (a strong and mobile type of nervous system), an investigator can proceed from knowing that the pace, rhythm, and intensity of the interrogation may be high, but not so long with a choleric, the introductory stage of the interrogation and the long establishment of contact may be reduced to a minimum, and the transition from one topic to another may be performed without lengthy preliminary preparation.

In the situation of interrogation with this type of witness, the focus on social desirability of their actions induces sanguine and, to a greater extent, choleric people to give false testimony without any intentional motivation behind the reported information. It is necessary to account for this fact when preparing for an interrogation, develop a list of test questions, and prepare evidence for presentation.

When questioning phlegmatic people (a strong and stable but less mobile type of nervous system), it should be borne in mind that this type is "stickin-the-mud" and needs a longer adaptation to the situation of interrogation due to the long period of time required for involvement in the dialogue. Therefore, the dynamics of the interrogation are characterized by a large introductory part and the stage of establishing contact and a slow transition from one episode to another, the pace of the conversation is relatively slow. 
Marina Anatoleyvna Kaluzhina, Vadim Victorovich Verstov, Yuri Alekseevich Bondarenko, Tatiana Sergeevna Balugina y Alexander Ivanovich Natura

656 The effect of individual differences on the cognitive processes of a witness during interrogation

Convinced of their mission as a witness, a phlegmatic person is very valuable because of their accuracy of perception and ability to engage in questioning for long periods of time without cognitive decline.

When interrogating melancholic witnesses (a weak type of nervous system), it is necessary to account for their tendency to intense deceleration in difficult life situations (such as an interrogation). This type of witness requires a special approach, as high levels of tension can lead to lethargy, apathy, and anxiety and make it difficult to establish contact and dialogue in an interrogation (Vedernikov, 1968).

Therefore, the main task of an investigator is to establish contact with them on a topic close to the subject of theinterrogation. This allows a relatively smooth transition to communication without crossing the subjective level of stress of such a witness beyond which they become objectively unable to give accurate and truthful testimony due to a significant decrease in cognitive abilities.

\section{Discussion}

Our findings regarding the patterns of cognitive ability in people of different temperaments suggest the need for allocating interrogation techniques suitable for each temperament. This approach is consistent with the results obtained in a different work on the state of persons undergoing interrogation.

It is found that it is most advantageous for the interrogator not to be overzealous in obtaining testimony and provide the person under interrogation with feedback in which hostile tactics toward them are minimized (Sambrano et al., 2021).

It should be noted that the results of our study are not universal as they cannot be applied to persons with mental illnesses or suffering from memory or cognitive disorders. In this regard, it is worth noting the research that determines the limits of interrogation techniques traditionally used in police practice and obtaining evidence (Manzanero and Palomo, 2020). In addition, such traditional interrogation techniques should be used with caution in the interrogation of persons possessing knowledge of the tactics of operative investigative measures (Khalymon et al., 2020).

Ultimately, the interrogator creates for themselves an information model of the prognosed object (Kaluzhina et al., 2019), in our case, the witness, and implements the pre-planned program of obtaining testimony from them. Therefore, a psychological approach to the analysis of personality, the temperament, and, accordingly, their effect on the cognitive abilities of a witness serves as a basic criterion for a positive outcome of witness interrogation. 
The results of this work should be used in conjunction with other techniques for both planning and conducting the interrogation. The most relevant additional interview preparation techniques should include the analysis of the non-verbal reactions of the interrogated based on videos from social media or exploratory interviewing. It should also be noted that additional tools ensuring successful interrogation have their own limitations on their effectiveness (Denault et al., 2020).

\section{Conclusion}

It is found that a specific structure of the interrogation plan emerges in regard to each type of temperament. This structure is determined by the speed of mental reactions and the opportunity to conduct long interrogations without cognitive decline on the part of witnesses.

The study demonstrates how the temperament and cognitive abilities of witnesses influence the effectiveness of interrogation techniques before and after the interrogation. The time interval is shown to largely change the effectiveness of perception of the posed questions depending on the temperament of the witness.

The underlying features of this state of affairs lie in the level of neuroticism and the manifestation of introversion and extraversion. Therefore, at the initial stage of the interrogation, the tactics of gathering information and assisting in recalling what has been forgotten should prevail over attempts to obtain the information sought from the witness. Depending on the witness's temperament, the tactics for their interrogation are selected accounting for the patterns of their cognitive abilities.

\section{Bibliographic References}

ANTONIAN, Yuri Miranovich; ENIKEEV, Marat Iskhakovich; EMINOV, Vladimir Evgenievich. 1996. Psychology of a criminal and crime investigation. Moscow, Russia.

AVERIN, Vyacheslav Afanasevich. 1999. Personality psychology: Textbook. Publishing House of V.A. Mikhailov. Saint Petersburg, Russia.

BALIN, Viktor; IL'INA, Valentina. 2020. «From interdisciplinary synthesis to integration of knowledge in legal psychology» In: Psikhologicheskii Zhurnal. Vol. 41, No. 3, pp. 92-103.

DENAULT, Vincent; PLUSQUELLEC, Pierrich; JUPE, Louise M; STYVES, Michel; DUNBAR, Norah E. 2020. "The Analysis of Nonverbal 
Marina Anatoleyvna Kaluzhina, Vadim Victorovich Verstov, Yuri Alekseevich Bondarenko, Tatiana Sergeevna Balugina y Alexander Ivanovich Natura

658 The effect of individual differences on the cognitive processes of a witness during interrogation

Communication: The Dangers of Pseudoscience in Security and Justice Contexts”, In: Anuario de Psicología Jurídica. Vol. 30, No. 1, pp. 1-12.

ENIKEEV, Marat. 1996. Fundamentals of general and legal psychology: textbook for universities. Iurist. Moscow, Russia.

GIPPENREITER, Iulia Borisovna. 2001. Psychology of attention (Series: Psychology textbook). CheRo. Moscow, Russia.

GRANOVSKAIA, Rada Mikhaylovna. 1997. Elements of practical psychology. Svet. Saint Petersburg, Russia.

HORÁK, Filip; LACKO, David; KLOCEK, Adam. 2021. "Legal Consciousness: A Systematic Review of its Conceptualization and Measurement Methods" In: Anuario de Psicología Jurídica. Vol. 31, No. 1, pp. 9-34.

KALUZHINA, Marina; MAKARENKO, Tamara; SPASENNIKOVA, Marina; VEDERNIKOVA, Tatiana. 2019. "The Methods of Digital Forecasting of Inmate Misconduct in Penal Institutions". In: Russian Journal of Criminology. Vol. 13, No. 5, pp. 747-756.

KASHAPOV, Mergalas Mergalimovich; SERAFIMOVICH, Irina. 2020. "Suprasituational thinking as person's cognitive resource in the context of professionalization” In: Psikhologicheskii Zhurnal Vol. 41, No. 3, pp. 4352.

KHALYMON, Serhiy; POLOVNIKOV, Vadym; VOLYNETS, Pavlo. 2020. "Socio-psychological Profile of a Person Who Confidentially Provides Assistance to the Operational Unit” In: Anuario de Psicología Jurídica. Vol. 30, No. 1, pp. 13-20.

KRIVOSHEIN, Ivan T. 2001. Theoretical and applied problems of interrogation of the accused. Tomsk University Publishing House. Tomsk, Russia.

LEONOV, Nikolay. 2018. "Interaction of man and the world in the paradigm of conflictology” In: Phsicologicheskiy Zhurnal. Vol. 5, pp. 109-112.

MANZANERO, Antonio L; PALOMO, Rubén. 2020. "Dissociative Amnesia beyond the Evidence about the Functioning of Memory" In: Anuario de Psicología Jurídica. Vol. 30, No. 1, pp. 43-46.

MIRONOVA, E. E. 2005. Collection of psychological tests. Women's Institute Envila. Minsk, Belarus.

MORGAN, Robert; ALISON, Laurence; PALACE, Marek; SHORTLAND, Neil; HUMANN, Michael. 2020. "The Effects of Intelligence and Personality on Performance in Simulated Interrogation Scenarios" In: Journal of Police and Criminal Psychology. 
PROHOROV, Aleksandr. 2020. "Structure-functional model of mental regulation of subject's psychic states" In: Psikhologicheskii Zhurnal. Vol. 41, No. 1 , pp. 5-17.

RATINOV, Aleksandr Ruvimovich. 1967. Forensic psychology for investigators: textbook. Nauchno-issledovatelskii i redaktsionnyi otdel. Moscow, Russia.

RUDENKO, Aleksandr Viktorovich; SENCHIKOVA, Maria Vadimovna. 2021. "Application of standards of proof in courts of general jurisdiction" In: Obshchestvo: Politika, Ekonomika, Pravo. Vol. 5, pp. 58-62.

SAMBRANO, Deshwan; MASIP, Jaume; BLANDÓN-GITLIN, Iris. 2021. "How emotions affect judgement and decision making in an interrogation scenario" In: Legal and Criminological Psychology. Vol. 26, No. 1, pp. 6282.

SOLDZ, Stephen; OLSON, Bradley; ARRIGO, Jean Maria. 2017. "Interrogating the ethics of operational psychology" In: Journal of Community Applied Social Psychology. Vol. 27, No. 4, pp. 273-286.

SWANNER, J.K.; MEISSNER, C.A; ATKINSON, D.J; DIANISKA, R.E. 2016. "Developing Diagnostic, Evidence-Based Approaches to Interrogation" In: Journal of Applied Research in Memory and Cognition. Vol. 5, No. 3, pp. 295-301.

VEDERNIKOV, Nikolay Trofimovich. 1968. Study of the criminal's personality in the process of investigation. Tomsk University Publishing House. Tomsk, Russia.

VILENSKAYA, Galina. 2020. "Emotional regulation: factors of development and forms of manifestation in behavior". In: Psikhologicheskii Zhurnal. Vol. 41, No. 5, pp. 63-76.

VRIJ, Aldert; LEAL, Sharon; FISHER, Ronald P; MANN, Samantha; DEEB, Haneen; JO, Eunkyung; CASTRO CAMPOS, Claudia; HAMZEH, Samer. 2019. «The Efficacy of Using Countermeasures in a Model Statement Interview» In: The European Journal of Psychology Applied to Legal Context. Vol. 12, No. 1, pp. 23-34. 

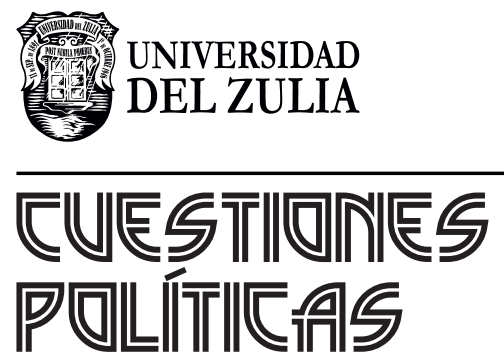

Vol. 39 N $^{\circ} 71$

Esta revista fue editada en formato digital y publicada en diciembre de 2021, por el Fondo Editorial Serbiluz, Universidad del Zulia. Maracaibo-Venezuela 